\title{
The Role of Internal and External Factors on Audit Quality
}

\author{
Inneke Agustina ${ }^{1 *}$, Emmy Indrayani ${ }^{2}$ \\ $\left.{ }^{1 *}, 2\right)$ Accounting, Economy, Gunadarma University \\ Pondok Cina, Depok, Jawa Barat, 16424 \\ E-mail:innekeas@gmail.com ${ }^{1 *}$
}

\begin{abstract}
Financial statements must be presented with information that is reasonable, reliable, and transparent, so it need to be audited by third parties. However, some cases involving external auditors often occur due to integrity inability. This research aims to analyze whether the internal (Professional Ethics, Independency, Experience) and external (Audit Tenure, Audit Fee) factors have a role or effect on Audit Quality. The analysis method used is Partial Least Square (PLS) using SmartPLS version 3.2.8. The data has been collected by questionnaires filled by 65 external auditors in South Jakarta who were selected using a purposive sampling. The results show that Professional Ethics and Audit Tenure affect significantly on Audit Quality. While Independency, Experience, and Audit Fee do not affect significantly on Audit Quality. Audit Tenure is the most dominant affected Audit Quality. The results of this research are expected to be a recommendation to improve the auditor's professional ethics in carrying out his duties.
\end{abstract}

Keyword: Audit Quality; Auditing, External Auditor; Public Accounting Firm

\section{INTRODUCTION}

With the rapid development of go public companies, especially in Indonesia, requests for auditing financial statements has been increased. This is because the company's financial statements are the report that contains the company information which is needed by parties who will be involved in the company, whether internal and external. However, there is an asymmetry of company's financial information and a potential interest conflict between the company and users of financial information from external parties, so that the company's financial statements need to be audited by third parties to assess the fairness of the financial statements which is reported by management (Fajrin, 2015). From the profession of a public accountant, the public expects a free and impartial assessment of the information presented by the company in financial statements (Dehilmus, 2017).

Tjun, Marpaung, and Setiawan (2012) stated that audit quality is the probability that an auditor will find and report violations in his client's accounting system. Besides, Sari and Lestari (2018) stated that audit quality is a systematic examination and independence to determine activities, quality, and results appropriate with planned arrangements and whether those arrangements are affectively implemented appropriately with the objectives.

Considering the role of auditors is needed by the business community, auditors have an 
obligation to maintain the standards of their ethical behavior on the organizations in their office, their profession, public, and themselves (Syahrani, 2014). Each auditor is expected to uphold the professional ethics that established by the Indonesian Institute of Certified Public Accountants (IAPI) and International Standards on Auditing (ISA), whether to improve audit quality, the reputation of public accountant firms, and the quality of the auditor. If the auditors do violate, the problem doesn't only occur for the theirself, but also for the public accountant firm that concerned, such as the congealeding of the permit period for the office or profession.

The problem of the low quality of audits has become the focus of the public in recent years with the involvement of public accountants. This caused several public accountants firms and/or public accountants in Indonesia have been suspended by the Indonesian Minister of Finance for their violations. One of them is Ben Ardi Public Accountant, CPA. from the Public Accountants Firm of Jamaludin, Ardi, Sukimto, and Rekan in Central Jakarta, based on the Decree of the Minister of Finance Number 445/KM.1/2015 for 6 (six) months, starting from May 29th, 2015 (Sanjaya and Nurbaiti, 2018).

Tjun, Marpaung, and Setiawan (2012) argued that audit firms that are well-established and have many clients are considered to have a higher level of independence because each client is considered insignificant to the large audit firms individually. But in the past few years, this statement has been difficult to prove, especially in Indonesia. The size of a public accounting firm is not a guarantee for the occurrence of irregularities in auditing financial statements conducted by auditors.

Based on these descriptions, researchers are interested in analyzing factors that effect on audit quality. The factors used in this research are professional ethics, independency, experience, audit tenure, and audit fee. This research involved respondents from external auditors who are working at the Public accounting firms in South Jakarta, whose involvement in giving opinions on the determination of audit quality was representative and useful in this research. Therefore, the researcher raised the title "The Role of Internal and External Factors on Audit Quality”.

Alfiati (2017) argued that auditor professional ethics is a science that discusses an auditor's critical attitude in acting that is following the morality and professional ethical standards that apply to his work as an accountant. The auditor professional ethics is a science that discusses an auditor's critical attitude in acting that is accordance with the morality and professional ethical standards that applicable to his work as an accountant.

When an auditor acts for the public interest, each practitioner must comply with and 
apply all the basic principles and rules of professional ethics that stipulated in the Ethics Code of Public Accountant. Based on the Ethics Code of Public Accountant Section 100 No. 04, every practitioner must comply with the basic principles of professional ethics, there are the principles of integrity, objectivity, secrecy, competency, professional attitudes, and prudence, and professional behavior. H1: Professional ethics significantly affects audit quality.

Based on the Audit Standard Statement (PSA) No. 04 (SA Section 220), independent means free from influence, because an auditor carries out his work in the public interest. An independent external auditor is an auditor who is not easily influenced, impartial to anyone, and obliged to be honest not only to the management and owners of the company but also to creditors and other parties who place trust in the auditor's work.

According to the Audit Standards Statement (PSA) and the Ethics Code of Public Accountant, the need for an auditor is to maintain its independence. Auditors who are independent in carrying out their duties are auditors who are neutral and impartial to any party to avoid conflicts of interest. If a conflict of interest causes a threat to one or more basic principles of professional ethics that cannot be eliminated or reduced to an acceptable level through the application of appropriate prevention, the practitioner (auditor) must refuse to accept the engagement or even resign from one or more engagements which have such interests (IAPI, 2016). Also, according to the Ethics Code of Public Accountant Section 290 No. 08, independence consists of 2 (two) types, there are independence of thought and independence of appearance. $\mathbf{H}_{2}$ : Independency significantly affects audit quality.

Turangan et al. (2016) suggested that an experience is a form of skill of an employee that is based on the length of work that a person has on an assignment or job position, which can be added value to support the creation of good and satisfying work results. Experience is a form of skill of an employee that is based on the length of work that a person has on an assignment or job position, which can be added value to support the creation of good and satisfying work results.

If someone wants to be a public accountant, then first, he must seek professional experience under the supervision of a more experienced senior accountant. In general, the government and public accounting firm require people that at least 2 (two) to 3 (three) years as a reputable accountant in Indonesia, especially in auditing, to obtain licenses in the public accountant profession (Dehilmus, 2017). H3: Experience significantly affects audit quality.

Aisyah et al. (2015) suggested that the audit tenure is the period between the auditor and the client regarding the agreed of audit services. Audit tenure can have an impact on the 
auditor's performance at the client's company such as the emotional relations of the auditor with the client, independence, audit fee, professionalism work, competency, etc.

Regulations about audit tenure are contained in the Financial Services Authority Regulation (POJK) No. 13/POJK.03/2017 about the Use of Public Accountant Services and Public accounting firms in Financial Services Activities (OJK, 2017).

This regulation is about the provision of general audit services for the financial statements of an entity that carried out by the same public accountant for only 3 (three) years of continuous engagement. While the provision of general audit services on the financial statements of an entity is carried out by a public accounting firm, depending on the results of the Audit Committee's evaluation of the potential risks for the use of services from the same public accounting firm for a long period. H4: Audit tenure significantly affects audit quality.

Sinaga and Rachmawati (2018) suggested that the audit fee is the cost that given by the client to the external auditor through a public accounting firm, taking into account in the various things that needed to carry out the audit services of the company's financial statement. The audit fee is the cost that given by the client to the external auditor through a public accountant firm, taking into account in the various things that needed to carry out the audit services of the company's financial statement.

According to the Institut Akuntan Publik Indonesia (2016), in establishing audit fees, public accounting firms and public accountants must consider the following matters, such as client needs, legal duties and responsibilities, independency, level of expertise and responsibility inherent the job, the level of complexity of task or job, the time that needed effectively used by the office of the public accountant and its staff to complete the work, and the agreed basis of fee determination. H5: Audit fee significantly affects audit quality.

Junaidi et al. (2016) defined that audit quality is the auditor's attitude which reflected in the results of his audit in the form of an audit opinion, on a material misstatement of financial statements and the results are reliable by the client. The audit quality is the auditor's attitude which reflected in the results of his audit in the form of an audit opinion, on material misstatement of financial statements and the results are reliable by the client. Based on Indonesia's Supreme Audit Agency (BPK) Regulation No. 1 of 2007 about Standards for Examining State Finance (SPKN) in Efendy (2010), audit quality is measured based on the quality of the process (the accuracy of audit findings, skepticism), quality of results (value of recommendations, clarity of reports, benefits of audits), and quality of follow-up audit results. 


\section{RESEARCH METHOD}

Population is a generalization area consisting of subjects that have certain qualities and characteristics set by researcher to be studied and made a conclusion. Whereas, the sample is part of the population. Sampling technique is a way to determine the sample whose amount is in accordance with the sample size that will be used as the actual data source, taking into account the characteristics and distribution of populations in order to obtain a representative sample (Hidayat 2017).

In this research, the population which used is external auditor who works at the public accountant firm in South Jakarta. Determination of samples in this research using purposive sampling, which is the sampling based on certain consideration or criteria that has been determined. It is obtained for a minimum sample is 55 samples/respondents, with minimum of experience working as an auditor for 1 (one) year and working in a public accountant firm in the South Jakarta area.

The method of data analysis in this research using SmartPLS version 3.2.8 with PLS (Partial Least Square) approach. The type of data in this research is data primer. The primary data in this research contained the personal characteristics of the respondents in the form of the name of the public accountant firm, gender, age, recent education, auditor experience, functional positions, and questionnaire answers to professional ethics, independency, experience, audit tenure, audit fee, and audit quality which uses a Likert scale with units of points $1-5$, which is scale 1 shows the answer of "strongly disagree" until the scale 5 shows the answer of "strongly agree".

Data has been collected by questionnaires filled by 65 external auditors who work at the public accounting firm in South Jakarta. Determination of samples in this research using purposive sampling, which is the sampling based on certain considerations or criteria that have been determined.

In this research, the outer model that used is a reflective indicator model. So, 2 (two) tests should be done, there are outer model test (validity and reliability test) and inner model test (regression coefficient and goodness of fit test). There are several reasons why PLS was used in a research.

First, PLS (Partial Least Square) is a method of data analysis based on the assumption that the sample does not have to be large, but the number of samples that is less than 100 can be analyzed. Second, PLS (Partial Least Square) does not dispute the normality of the distribution of a data. Third, PLS (Partial Least Square) can be used to analyze theories that are still has weak power, because PLS can be used for predictions. 
Fourth, on the PLS (Partial Least Square) approach, it is assumed that all variance measures can be used to explain. Also, the PLS (Partial Least Square) approach is a variantbased structural equation (SEM) analysis that can simultaneously testing the measurement models while testing the structural models (Hussein, 2015).

Based on the above hypothesis formulation and literature review, the framework of this study is as follows:

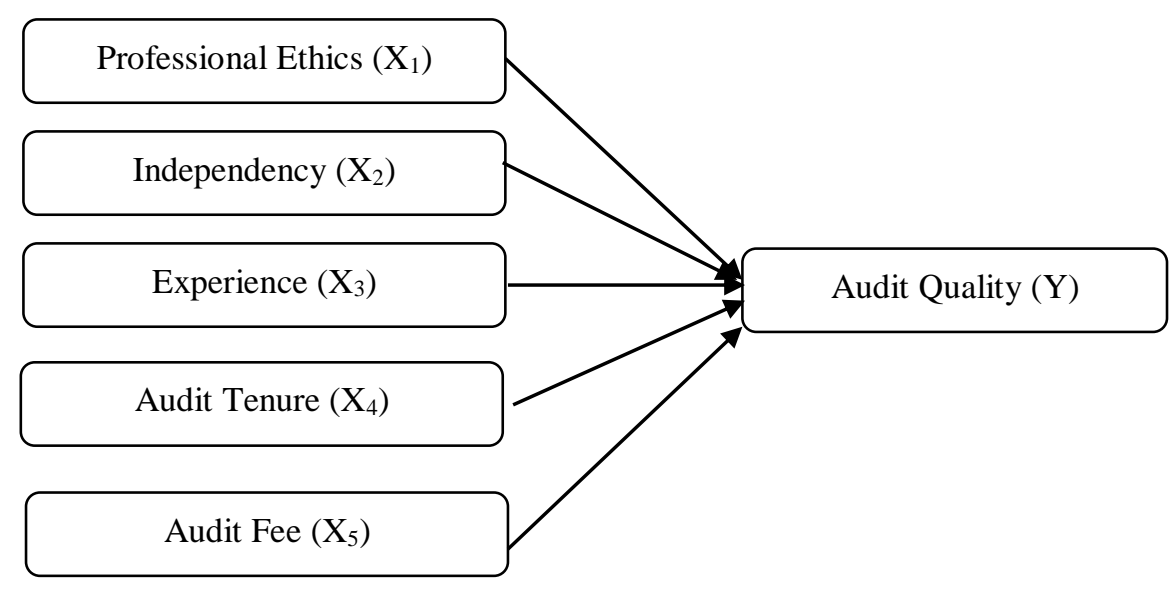

Figure 1. Framework Research

Source: processed for this research (2019)

\section{RESULT AND DISCUSSION}

The demographic characteristics of the respondents in this reserach were the profiles of 65 external auditors who were being respondents in filling out this questionnaire. Demographic characteristics of respondents included gender, age, recent education, experience as an auditor, and functional positions.

The percentage of respondents in this research with male was 46\% (30 respondents) and female was 54\% (35 respondents). This shows that respondents with female gender were the most dominant respondents in this research.

According to Subroto and Irianto (2011), female auditors, especially external auditors are more often found than male auditors. This is because female auditors are more conservative than male auditors, especially in determining judgment audits. Public accountant services companies require auditors who are able to work carefully, especially in making audit decisions.

The percentage of respondents in this research with age of 21-25 years was 59\% (38 respondents), age of 26-30 years was 26\% (17 respondents), age of 31-35 years were 6\% (4 
respondents), age of 36-40 years were $6 \%$ (4 respondents), and age of $>40$ years were $3 \%$ ( 2 respondents). This shows that respondents with age of 21-25 years were the most dominant respondents in this research, as many as 38 respondents (59\%). Meanwhile, respondents with age of $>40$ years were the least respondents in this research, as many as 2 respondents (3\%).

According to Yanti et al. (2014), young auditors aged 21-25 years are more often found, especially in the office. This is because the accountant services company requires a fresh graduate auditor who is believed to still understand correctly about audit knowledge during college.

The percentage of respondents in this research with the Bachelor degree was 97\% (63 respondents), the Master degree was 3\% (2 respondents), and the Doctoral degree was 0\% (0 respondent). This shows that the respondents with the Bachelor degree were the most dominant respondents in this research. Meanwhile, respondent with the Doctoral degree was the least respondent in this research. According to Yanti et al. (2014), that related to age, it can be said that external auditors who have a Bachelor degree are more often to found than auditors which are holding Master or Doctoral degree.

The percentage of respondents in this research with experience as an auditor for $<1$ year was $0 \%$ ( 0 respondent), for 1-5 years were 89\% (58 respondents), for 6-10 years were $11 \%$ ( 7 respondents), and for $>10$ years was $0 \%$ ( 0 respondent). This shows that respondents with experience as auditor for 1-5 years were the most dominant respondents in this research. Meanwhile, respondents with experience as an auditor for $<1$ year and $>10$ years were the least respondent in this research. The specific reason for respondent with experience as an auditor for $<1$ year is that the researcher establishes the terms or characteristics of the respondent with a minimum of 1 year experience as an auditor.

According to Singgih and Bawono (2010), because there are more young external auditors, ranging from 21-25 years old, and holding a Bachelor degree or fresh graduates, then there is a possibility that in a research, the most dominant respondents were respondents who had experience working as auditor for less than 3 years.

The percentage of respondents with functional position as junior auditor was $62 \%$ (40 respondents), as senior auditor was 38\% (25 respondents), and 0\% (0 respondent) in each category of consultant, partner, and others. This shows that respondents with functional position as junior auditors are the most dominant respondents in this research. Meanwhile, respondents with functional position as consultant, partner, and others were the least respondents in this research. Related to Yanti et al. (2014), because the external auditor is a young people and is a fresh graduate from a university, then the position held is junior 
auditor. More junior auditors are found in the office.

Testing instrument research in terms of both validity and reliability show that the results of the research instruments used are valid, where the value of convergent validity is $\geq$ 0,70 and the value of each construct are higher when compared to another construct in the same row, the value of composite reliability is $\geq 0,70$, the value of Cronbach's Alpha is $\geq$ 0,60 , and the value of $\mathrm{AVE}$ is $\geq 0,50$.

The goodness of fit value in this research shows in $\mathrm{R}^{2}$, it is 0,629 . The goodness of fit values in this research are shown in the following Table I.

Table 1. R-Square

\begin{tabular}{lll} 
& R-Square & Percentage \\
\hline $\mathbf{Y}$ & 0,629 & $62,9 \%$ \\
\hline
\end{tabular}

Source: Data Primer Processed (2019)

This shows that the Professional Ethics $\left(\mathrm{X}_{1}\right)$, Independency $\left(\mathrm{X}_{2}\right)$, Experience $\left(\mathrm{X}_{3}\right)$, Audit Tenure $\left(\mathrm{X}_{4}\right)$, and Audit Fee $\left(\mathrm{X}_{5}\right)$ can explain the effect on Audit Quality (Y) of 0,629 or 62,9\% simultaneously. Meanwhile, the remaining $\mathrm{R}^{2}$ of 0,371 or $37,1 \%$ can be explained by the effect of other factors or independent variables.

Test the value of Stone Geisser $\mathrm{Q}^{2}$ on the PLS approach using the manual method. The calculation of the $\mathrm{Q}^{2}$ test is as follows.

$$
\begin{aligned}
\mathrm{Q}^{2} & =1-\left(1-\mathrm{R}^{2}\right) \\
& =1-(1-0,629) \\
& =1-0,371 \\
& =0,629
\end{aligned}
$$

Notes:

$\mathrm{Q}^{2} \quad=$ Predictability capability of a structural model

$\mathrm{R}^{2} \quad=$ Value of coefficient of determination of a structural model

Based on the results of the calculation of the $\mathrm{Q}^{2}$ test described, it is shown that the influence of Professional Ethics $\left(\mathrm{X}_{1}\right)$, Independency $\left(\mathrm{X}_{2}\right)$, Experience $\left(\mathrm{X}_{3}\right)$, Audit Tenure $\left(\mathrm{X}_{4}\right)$, and Audit Fee $\left(\mathrm{X}_{5}\right)$ simultaneously have a $\mathrm{Q}^{2}$ value of 0,629 . This shows that the structural model in the study has good predictive capability because it is between the values of $0<\mathrm{Q}^{2} \leq$ 1 , which is 0,629 . The regression coefficient values in this research are shown in the following Table 2. 
Table 2. Regression Coefficient

\begin{tabular}{cccc}
\hline & Original Sample & T-Statistics & P-Values \\
\hline$\left(\mathrm{X}_{1}\right)->(\mathrm{Y})$ & 0,307 & 1,986 & 0,048 \\
$\left(\mathrm{X}_{2}\right)->(\mathrm{Y})$ & 0,040 & 0,221 & 0,825 \\
$\left(\mathrm{X}_{3}\right)->(\mathrm{Y})$ & 0,190 & 1,367 & 0,172 \\
$\left(\mathrm{X}_{4}\right)->(\mathrm{Y})$ & 0,362 & 2,482 & 0,013 \\
$\left(\mathrm{X}_{5}\right)->(\mathrm{Y})$ & 0,091 & 0,838 & 0,403 \\
\hline
\end{tabular}

Source: Data Primer Processed (2019)

The results of $\mathrm{p}$-values and t-statistics from the role of Professional Ethics $\left(\mathrm{X}_{1}\right)$ on Audit Quality $(\mathrm{Y})$ are $0,048(<0,05)$ and $1,986(>1,975)$, so the professional ethics significantly affects audit quality $\left(\mathrm{H}_{1}\right)$. This is because the respondent state that they will do their job in accordance to the principles which are in audit standards and code of ethics, also make the standards as a basis of their job, so they can make a good quality of audit and can be trusted by public and clients.

The Original Sample of this research has a positive value, which is 0,307. This shows that if an auditor explains the audit assignments in accordance with professional ethics or the applicable professional auditor's code of ethics, the audit results will be of good quality. Good audit quality reflects the attitude carried out by the auditor during the inspection in accordance with applicable standards or rules.

The results of this study support the results of the research obtained by Dewi (2014) which showed that professional ethics significantly affects audit quality. In her research, Dewi stated that an auditor in carrying out professional duties needs to be limited by a set of rules and standards in the form of professional ethics because this can affect the quality of the audit that will be produced. Also, she supported the results by stating that auditor performance in carrying out audit tasks should pay attention to the ethics of auditors to maintain audit quality standards.

The results of p-values and t-statistics of the role of Independency $\left(\mathrm{X}_{2}\right)$ on Audit Quality (Y) are 0,825 $(>0,05)$ and $0,221(<1,975)$, so independency does not significantly affect audit quality. This is because the respondent state that even though they should do their job following the audit standards, but they do not want to have a bad relation with the client. They will cooperate with the client as well, such as following what the client has desired, so independence might be ruled out.

Based on the results of observations in this research, it was shown that the auditor who 
has a close or long-standing relation with the client, agrees not to report all the errors that the client had. So that it can be said that even though an auditor knows that he must carry out inspection duties by applicable standards or rules, the independence of an auditor can still be affected if he thinks that it is better to maintain good relations with the client than the auditor must lose the old client, which allows an auditor is difficult to adapt to new clients.

The results of this research support the results of research that obtained by Turangan et al. (2016) which showed that independency does not significantly effect on audit quality. In their research, Turangan et al. states that independency is one of the most important characteristics for auditors and the basis of the principle of integrity and objectivity. However, independency can be affected by several factors such as the relationship of familiarity and the length of the auditor or the public account firm relations with the client.

The results of $\mathrm{p}$-values and t-statistics from the role of Experience $\left(\mathrm{X}_{3}\right)$ on Audit Quality (Y) are $0,172(>0,05)$ and 1,367 (<1,975), so experience does not significantly affect audit quality. This is because the respondent state that even though they have a big experience in auditing, it does not mean they can keep the integrity, independence, or other professional acts on their job which is it can effect on audit quality. If they have a big experience, but also have a crisis independence, they can not make a good audit quality.

Based on the results of observations in this research, the respondent of this research was dominated by respondents who had recent education as a Bachelor, aged 21-25 years and had work experience as auditors for 1-5 years. This shows that even though a respondent does not have much experience working as an auditor or is a fresh graduate, an auditor can still carry out inspection tasks properly. So, it can be said that the more experience increases, it does not affect the quality of the audit that produced as long as an auditor can carry out the task of inspection professionally.

The results of this research support the results of research obtained by Badjuri (2012) which showed that experience does not significantly effect on audit quality. In his research, it was concluded that the increasing experience of an auditor, does not affect the audit quality of the audit report produced. In their professional assignments, auditors are required to be able to maintain the quality of audit results in accordance with applicable audit standards. This demand makes auditors must follow professional audit procedures so that those who have just worked as auditors and who have long experience as auditors must maintain the quality of the results of the audit.

The results of $\mathrm{p}$-values and t-statistics from the role of Audit Tenure $\left(\mathrm{X}_{4}\right)$ on Audit Quality (Y) are 0,013 $(<0,05)$ and 2,482 (> 1,975), so audit tenure significantly affects audit 
quality $\left(\mathrm{H}_{4}\right)$. This is because the respondent state that the longer audit tenure, the more knowledge about the client that they can have. If they have a long of audit tenure, so they can make a good audit quality and give a good recommendation that is in accordance to client's situation and audit standards, so that financial statements can be trusted as well.

Based on the results of observations in this research, it was shown that the respondent agrees that the length of the audit tenure made auditor knowledge of the client company increasingly. The respondent also agrees to accept the engagement with the client company by applicable standards or laws, so as not to create a relation of intimacy that could affect the quality of the audit produced, which is only for 3 (three) years continuous with the same auditor.

This is stated in the Financial Services Authority Regulation (POJK) No. 13/POJK.03/2017 concerning Use of Public Accountant Services and Public accounting firms in Financial Services Activities. According to Pramaswaradana and Astika (2017), audit tenure that is run based on applicable rules can improve audit quality.

The results of this research support the results of research that obtained by Pramaswaradana and Astika (2017) which showed that audit tenure significantly effects on audit quality. In their research, Pramaswaradana and Astika stated that public accountant firms need to make changes to audit tasks. If the company does not make an audit assignment change, this will create a relations of intimacy between the auditor and the client. Also, audit tenure that is run based on applicable rules, can improve audit quality. The results of a similar research were also obtained by Dewi (2014) who showed that audit tenure can effect on the audit quality of an auditor.

The results of p-values and t-statistics from the role of Audit Fee $\left(\mathrm{X}_{5}\right)$ on Audit Quality (Y) are 0,403 $(>0,05)$ and $0,838(<1,975)$, so audit fee does not significantly affect audit quality. This is because the respondent state that the audit fee has been determined by standards or the basis of the audit fee. Because of it, the auditor does not feel a dilemma when doing their job. So that, the auditor still can make a good audit quality without being dizzy about the amount of audit fee.

Based on the results of observations in this research, it was shown that the respondent agrees if the client company provided an audit fee following the assignment risk, work complexity, auditor's level of expertise, timeframe for conducting the audit, and by the applicable designation basis. Thus, the auditor does not feel dilemmatic about the size of the audit fee and keeps the audit quality following applicable audit standards. The auditor can refuse if the audit fee provided by the client is not following several factors that have` 1 been 
described.

The results of this research support the results of research that obtained by Campa (2013) which showed that audit fee does not significantly effect on audit quality. In his research, it was concluded that the amount of the audit fee was determined based on several factors such as assignment risk, work time efficiency, and the complexity of the tasks or services provided. So, if the audit fee is not in accordance with the three things described, the auditor may reject the engagement relationship with the requesting client company. Because of this, the size of the audit fee will not effect on audit quality because the auditor will carry out the task only if the audit fee is given in accordance with the applicable determination basis.

\section{CONCLUSION AND RECOMMENDATION}

Based on the results of this research, we can conclude that the Professional Ethics $\left(\mathrm{X}_{1}\right)$ and Audit Tenure $\left(\mathrm{X}_{4}\right)$ significantly affects Audit Quality $(\mathrm{Y})$, the Independency $\left(\mathrm{X}_{2}\right)$, Experience $\left(\mathrm{X}_{3}\right)$, and Audit Fee $\left(\mathrm{X}_{5}\right)$ do not significantly affect Audit Quality (Y). Based on the results of the research described, Audit Tenure $\left(\mathrm{X}_{4}\right)$ is the most dominant factor in affecting Audit Quality (Y).

Professional ethics significantly effects on audit quality. The effect of professional ethics on audit quality in this research has a positive value. This shows that the higher the application of auditor professional ethics in the implementation of audit tasks, the better the quality of the audit produced. Good audit quality reflects the auditor's attitude during the implementation of audit duties in accordance with audit standards and the applicable professional code of ethics. With the implementation of professional ethics or morality in the auditor, it will reduce the level of fraud in the audit results and increase public confidence in the profession of auditors, especially external auditors.

Independency does not significantly effect on audit quality. This is because the independency of an auditor can be affected by several factors, such as the relations of familiarity in establishing business relations or engagement with clients. This is indicated by the opinion of the respondents stating that the auditor will not report all client errors in order to maintain a good relations with the client, especially if the engagement relations has been going on for a long time. The audit results are also in accordance with the wishes of the client, but do not guarantee compliance with applicable audit standards.

Experience does not significantly effect on audit quality. This shows that much or at least the experience of someone working as an auditor does not effect on the quality of the audit produced. An auditor who has a little experience working as an auditor can produce 
good audit quality as long as he is able to carry out audit tasks in accordance with applicable audit standards and professional code of ethics. An auditor who has a lot of experience working as an auditor, does not guarantee that it can produce good audit quality if he is not able to carry out audit tasks in accordance with the applicable audit standards and professional code of ethics.

Audit tenure significantly effects on audit quality. The effect of audit tenure on audit quality in this research has a positive value. This shows that the longer the business relations or engagement of the auditor and the client, the better the quality of the audit produced. The length of the audit tenure can increase the auditor's knowledge of the client company, especially in getting the data and information which needed for the implementation of audit tasks. Extensive auditor knowledge about client companies, can facilitate the auditor in detecting and reporting client errors, as well as providing constructive recommendations for client companies.

Audit fee does not effect significantly on audit quality. This shows that the size of the audit fee does not provide a sense of dilemma to the auditor related to the work carried out. The amount of the audit fee is determined by several factors such as assignment risk, auditor's skill level, work complexity, and work time span based on the applicable designation basis. Thus, the auditor can refuse business or engagement with the client if the agreement to provide an audit fee is not in accordance with applicable regulations.

This research has some limitations, there are only use 5 (five) independent variables and the sampling area is only for Public Accountant Firms in South Jakarta. Based on those conclusions and limitations, the recommendations are for further research, external auditors, and public accounting firms. First, further research can use a larger number of samples, expand the research area, add other independent variables, and add other or more objects research so that the observations obtained are more complete and accurate. Also, the further research can develop the method or approach for this research.

Second, for external auditors and public accounting firms in improving good audit quality such as external auditors can carry out inspection tasks by applying applicable audit standards and professional codes of ethics, external auditors can improve the independency, experience, integrity, and objectivity to produce good audit quality, which applicable to audit standards, and the public accounting firm and the audit team can apply the applicable audit tenure and audit fee standards so that these things do not effect on the auditor's attitudes and morality. 


\section{REFERENSI}

Aisyah, F., Gunawan, H., \& Purnamasari, P. (2015). Pengaruh Audit Rotation dan Audit Tenure terhadap Kualitas Audit dengan Fee Audit sebagai Variabel Pemoderasi (Studi pada Manufaktur yang Terdaftar di BEI Tahun 2012-2014). Seminar Penelitian Sivitas Akademika Unisba, 1(2), 1-10.

Alfiati, R. (2017). Pengaruh Etika Auditor, Skeptisme Profesional, dan Kompetensi Auditor terhadap Kualitas Hasil Audit (Studi Empiris pada Kantor Inspektorat Provinsi Sumatera Barat). Jurnal Akuntansi, 5(1), 1-28.

Badjuri, A. (2012). Analisis Faktor-Faktor yang Mempengaruhi Kualitas Hasil Pemeriksaan Audit Sektor Publik (Studi Empiris pada BPKP Perwakilan Jawa Tengah). Dinamika Akuntansi, Keuangan, dan Perbankan, 1(2), 120-135.

Campa, D. 2013. Big 4 Fee Premium and Audit Quality. Managerial Auditing Journal, 28(8), 680-707.

Dehilmus, I. (2017). Pengaruh Kompetensi dan Independensi terhadap Kualitas Audit dengan Pengalaman Kerja sebagai Variabel Moderasi pada Kantor Akuntan Publik (Studi Empiris pada Kantor Akuntan Publik Korwil Sumatera bagian Tengah). JOM FEKON, 4(1), 3196-3210.

Dewi, R. M. (2014). Pengaruh Due Professional Care dan Etika Auditor terhadap Kualitas Audit (Studi pada Kantor Akuntan Publik di Wilayah Kota Bandung yang Terdaftar di BAPEPAM-LK). Skripsi. Fakultas of Economy of Komputer Indonesia University. Bandung

Efendy, M. T. (2010). Pengaruh Kompetensi, Independensi, dan Motivasi terhadap Kualitas Audit Aparat Inspektorat dalam Pengawasan Keuangan Daerah. Tesis. Magister of Science of Accounting Diponegoro University. Semarang

Fajrin, F. (2015). Pengaruh Diferensiasi Kualitas Audit, Kesulitan Keuangan Perusahaan, Opini Audit, Kepemilikan Institusional dan Fee Audit terhadap Pergantian KAP (Studi Empiris pada Perusahaan Manufaktur yang Terdaftar di BEI Periode 2011-2013). JOM FEKON, 2(2), 1-13.

Institut Akuntan Publik Indonesia (IAPI). (2016a). Kode Etik Profesi Akuntan Publik. Jakarta. Institut Akuntan Publik Indonesia (IAPI). (2016b). Standar Audit. Jakarta.

Junaidi, Hartadi, B., \& Yurianto, P. S. (2016). Kualitas Audit: Sebuah Kajian Teoritis. IARN, 4(1), 21-34.

Otoritas Jasa Keuangan (OJK). (2017). Peraturan Otoritas Jasa Keuangan (POJK) No. 13/POJK.03/2017 tentang Penggunaan Jasa Akuntan Publik dan Kantor Akuntan Publik dalam Kegiatan Jasa Keuangan. Jakarta.

Pramaswaradana, I G. N. I. \& Astika, I. B. P. (2017). Pengaruh Audit Tenure, Audit Fee, Rotasi Auditor, Spesialisasi Auditor, dan Umur Publikasi pada Kualitas Audit. E-Jurnal Akuntansi Universitas Udayana, 19(1), 168-194.

Sanjaya, V. E. \& Nurbaiti, A. (2018). Pengaruh Independensi, Objektivitas, Etika, Kompetensi, dan Profesionalisme terhadap Kualitas Audit (Studi Empiris pada Kantor Akuntan Publik di Bandung). E-Proceeding of Management, 5(3), 3402-3411. ISSN: 2355-9357. Bandung: Telkom University.

Sari, E. N. \& Lestari, S. (2018). Pengaruh Kompetensi dan Time Budget Pressure terhadap Kualitas Audit pada BPK RI Perwakilan Provinsi Sumatera Utara. Jurnal Riset Akuntansi dan Keuangan, 6(1), 81-92.

Sinaga, E. A. \& Rachmawati, S. (2018). Besaran Fee Audit pada Perusahan yang Terdaftar di Bursa Efek Indonesia. Media Riset Akuntansi, Auditing, dan Informasi, 18(1), 19-34.

Tjun, L. T., Marpaung, E. I., \& Setiawan, S. (2012). Pengaruh Kompetensi dan Independensi Auditor terhadap Kualitas Audit. Jurnal Akuntansi, 4(1), 33-56.

Turangan, G. M., Karamoy, H., \& Tinangon, J. J. (2016). Faktor-Faktor yang Memengaruhi 
Kualitas Audit pada Inspektorat Provinsi Sulawesi Utara. Jurnal Accountability, 5(2), 119-140. https://doi.org/10.32400/ja.14430.5.2.2016. 